\title{
Hunian Vertikal Dengan Penerapan Pug-In City Di Semarang
}

\author{
Haji Luth Amirullah, Fauzan Ali Ikhsan, Ana Hardiana \\ Program Studi Arsitektur \\ Jurusan Arsitektur Fakultas Teknik \\ Universitas Sebelas Maret Surakarta \\ Email : ajiluth@gmail.com
}

\begin{abstract}
Semarang city is one of the largest cities in Indonesia that has many people lived. Just like any other major city, overpopulation resulting in overcrowding due to a growing population but the land remains. Flats used as a solution for housing in urban areas, due with an area is not too large but can accommodate a lot occupancy. Flats could be a solution to housing in urban areas but the house or dwelling unit on the flats is different to landed house. Landed house can develop, increase, decrease and change according to the needs and desires of its inhabitants, it is not found in the dwelling unit at flats. The problem is how to make multistorey housing that each unit dwellings such as landed house, could evolve and change according to the needs and desires of its inhabitants, even a dwelling unit can move from one place to another. The method used to apply the plug-in city in vertical housing, because the concept of plug-in city has thought that the main structure is permanent and has a longer period of time while its units are not permanent, has a separate structure, can be joined and separated of the main structure. Hunian Vertikal dengan Penerapan Plug-In City is a multistorey housing that each dwelling units can develop, change and move according to the needs and desires of its inhabitants.
\end{abstract}

Keywords : Plug-In City, Semarang, Vertical Housing,

\section{PENDAHULUAN}

Rumah susun merupakan salah satu solusi dari masalah kebutuhan papan di perkotaan yang padat. Sebelumnya perlu diketahui pengertian dari rumah menurut Budihardjo (1994), rumah tidak sekadar dilihat sebagai benda mati, produk atau komoditi yang mandek, melainkan sebagai jasad hidup atau proses yang dinamis. Berkembang terus sesuai dengan siklus kehidupan manusia, pertumbuhan keluarga dan peningkatan kondisi sosial ekonominya. Pemahaman tentang rumah dari Budihardjo (1994) tersebut, rumah merupakan hasil dari kebutuhan dan akan terus berkembang bersama penghuninya, rumah bukan sekadar produk jadi.

Apartemen atau rumah susun menjadikan hunian sebagai produk jadi yang bentuk dan ruangnya tidak dapat dikembangkan lagi. Berbeda dengan rumah tapak (landed house), pada tahap awal pembangunan perumahan massal, rumah sebagai produk jadi dengan beberapa ragam bentuk dan luas, namun setelah itu tiap rumah akan menyesuaikan dengan pertumbuhan penghuni, sehingga tiap rumah dapat memiliki bentuk dan ruang yang beraneka ragam. Terlihat bahwa rumah merupakan cerminan dari penghuni.

Perlu adanya rumah susun yang tiap unit hunian dapat disesuaikan dengan kebutuhan dan perkembangan penghuni. Tiap unit hunian akan menjadi beraneka ragam.

Rumah susun dengan konsep plug-in city memberi kebebasan namun dengan batasan (material dan struktur) bangunan kepada penghuni untuk membangun dan mengembangkan bentuk dan ruang unit huniannya sesuai dengan kebutuhan dan kondisi sosial ekonominya.

\section{METODE}

Perencanaan dan perancangan Hunian Vertikal dengan Penerapan Plug-In City di Semarang diawali dengan pengumpulan data yang berupa literatur tentang permukiman, rumah susun dan Kota Semarang. Data tentang permukiman dan rumah susun diperoleh permasalahan yaitu bagaimana membuat hunian yang dapat berkembang meskipun dalam bentuk rumah susun. Permasalahan tersebut diatasi dengan literatur tentang plug-in 
city. Hasil dari pengumpulan data yang dilakukan, diolah dan dijadikan bahan untuk menganalisis tapak, tampilan dan massa, kegiatan, pelaku dan ruang, dan struktur dan utilitas.

Menganalisis tapak untuk menentukan pencapaian menuju tapak, pintu masuk, sirkulasi dan pemintakatan. Menentukan pencapaian, pintu masuk, sirkulasi dan pemintakatan diperlukan, salah satunya untuk menentukan jalan bagi kendaraan besar yang berfungsi sebagai pengangkut hunian. Selanjutnya menganalisis tampilan dan massa, bentuk yang dihasilkan disesuaikan dengan modul-modul hunian, mega struktur dan penempatan crane yang dapat menyatu dengan bangunan. Tahap analisis struktur, menganalisis preseden struktur yang berkaitan dengan plug-in city.

Hasil dari analisis tersebut menjadi sebuah konsep dan desain dari Hunian Vertikal dengan Penerapan Plug-In City di Semarang.

\section{ANALISIS}

\subsection{Analisis Tapak}

Bertujuan untuk menetapkan tapak terpilih berdasarkan latar belakang dan kriteria tapak rumah susun.

1. Analisis Pemilihan Tapak

a. Latar Belakang

Kota Semarang masih membutuhkan hunian sekitar 43.400 unit rumah. Namun, kebutuhan hunian yang tinggi tidak dibarengi dengan lahan yang semakin berkurang.

b. Kriteria Tapak

Salah satu kriteria tapak untuk dibangun rumah susun adalah letaknya yang berada di pusat kota.

c. Tapak Terpilih

Lokasi tapak berada di Kelurahan Pandansari, Kecamatan Semarang Tengah. Terletak di Jalan Imam Bonjol (lihat Gambar 1) yang berdekatan dengan Stasiun Kereta Api Semarang Poncol. Berbatasan langsung dengan dua jalan di sebelah utara dan selatan tapak.

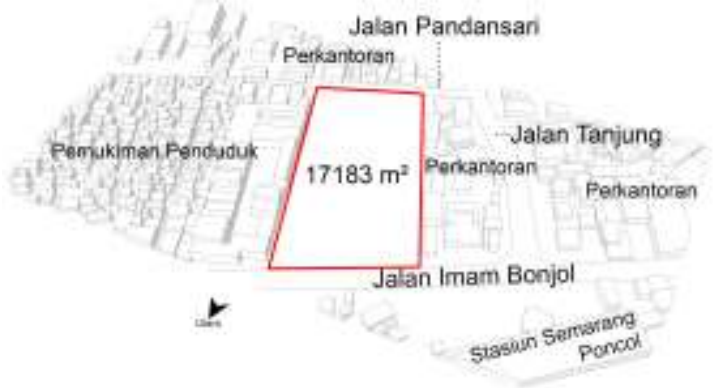

Gambar 1. Tapak

2. Analisis Pencapaian

Tapak Hunian Vertikal dengan Penerapan Plug-In City berhubungan erat dengan dua jalan yang keduanya dapat dilalui kendaraaan (lihat Gambar 2). Sebelah utara berhubungan dengan Jalan Imam Bonjol dan sebelah selatan dengan Jalan Pandansari. Jalan Imam Bonjol merupakan jalan yang lebih besar dibanding Jalan Pandansari, untuk kendaraan dan manusia akses menuju tapak dapat melalui dua jalan tersebut, namun untuk kendaraan pengangkut (kendaraan besar) baiknya melewati Jalan Imam Bonjol.

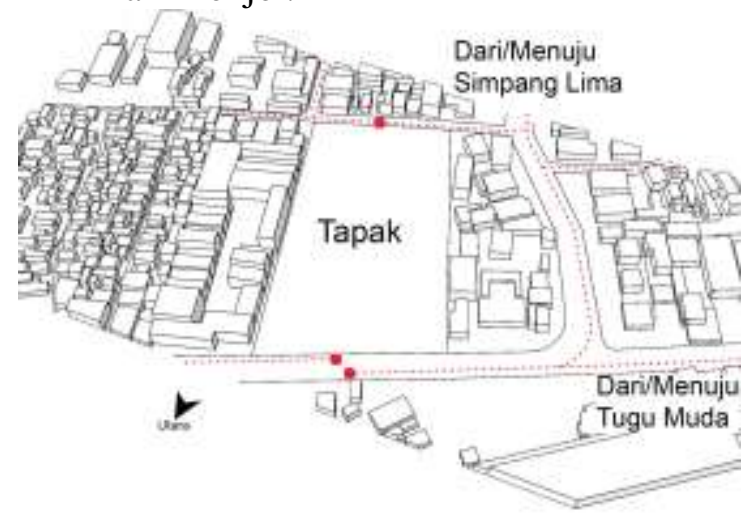

Gambar 2. Pencapaian

3. Analisis Pintu Masuk

Bertujuan untuk menentukan titik penghubung dari bagian luar dan bagian dalam tapak serta menentukan pintu masuk utama dan pintu masuk kedua (lihat Gambar 3).

Untuk menentukan pintu masuk utama dan pintu masuk kedua diperlukan kriteria dari keduanya.

Kriteria pintu masuk utama adalah :

a. Jalan yang lebar. 
b. Jalan yang dilalui banyak kendaraan.

c. Jalan yang mudah diakses baik oleh kendaraan maupun pejalan kaki.

Sedangkan kriteria pintu masuk kedua adalah :

a. Jalan yang biasanya lebih kecil dari jalan untuk pintu masuk utama.

b. Jalan yang tidak terlalu ramai dibanding jalan untuk pintu masuk utama.

c. Jalan yang mudah diakses baik oleh kendaraan maupun pejalan kaki.

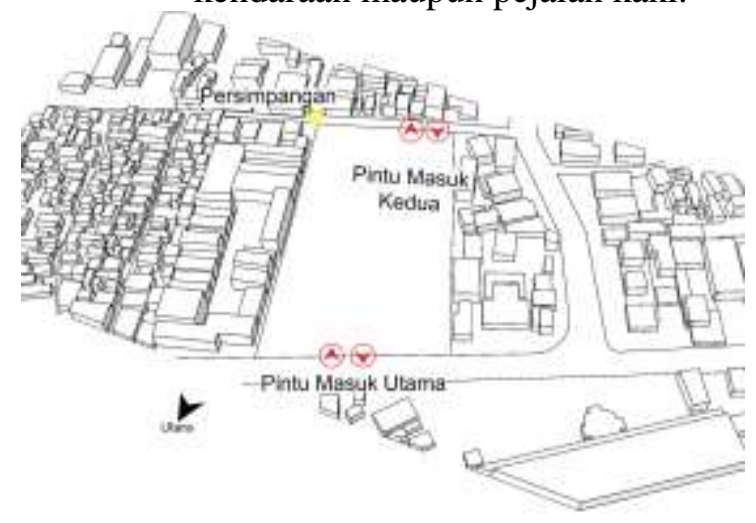

Gambar 3. Pintu Masuk

\section{Analisis Sirkulasi}

Sirkulasi pada rumah susun dengan konsep plug-in city terbagi menjadi tiga yaitu :

a. Sirkulasi manusia (biru), jalan atau jalur bagi manusia atau yang bukan kendaraan bermotor, berhubungan dengan pintu masuk dan keluar tapak, taman dan pintu masuk dan keluar bangunan. Terlihat pada Gambar 4, 5, 6.

b. Sirkulasi kendaraan (merah dan jingga), jalan atau jalur bagi kendaraan penghuni maupun pengunjung yang berhubungan dengan pintu masuk, pintu keluar dan tempat parkir. Terlihat pada Gambar 4, 5, 6 dengan warna merah untuk jalan mobil dan jingga untuk jalan motor.

c. Sirkulasi kendaran pengangkut hunian (kuning), konsep plug-in city tiap unit huniannya menggunakan modular yang dapat dibongkar-pasang dan dapat dipindahkan. Terlihat pada Gambar 4, 5, 6 .

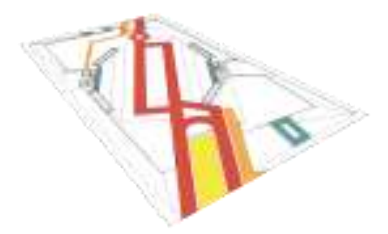

Gambar 4. Sirkulasi Lantai 1

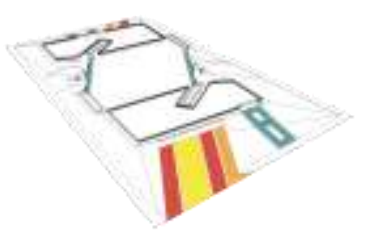

Gambar 5. Sirkulasi Lantai 2

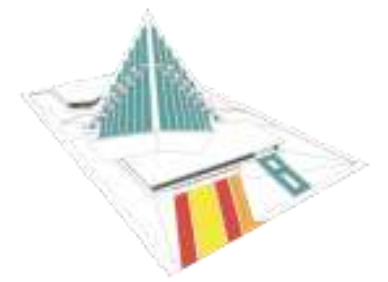

Gambar 6. Sirkulasi Lantai 3

\section{Analisis Pemintakatan}

Pemintakatan ditetapkan berdasarkan kegiatan, kegiatan utama dari rumah susun adalah menghuni yang masuk dalam area hunian. Kegiatan menghuni perlu kegiatan lainnya untuk mendukungnya, seperti utilitas yang masuk dalam area utilitas, kegiatan yang berkaitan dengan manusia lainnya atau kegiatan sosial masuk dalam area publik, serta tempat untuk menyimpan kendaraan dalam area parkir (lihat Gambar 7).

a. Area hunian, berupa unit hunian yang merupakan fungsi utama dari hunian vertikal.

b. Area utilitas, berupa ruang untuk kegiatan yang mendukung hunian. Seperti listrik, air, sampah, keamanan.

c. Area parkir, merupakan area untuk memarkirkan kendaraan bagi penghuni maupun pengunjung. 
d. Area publik, merupakan area yang berfungsi untuk publik (penghuni dan pengunjung) bersosial, baik berupa taman, tempat ibadah atau tempat berkumpul.

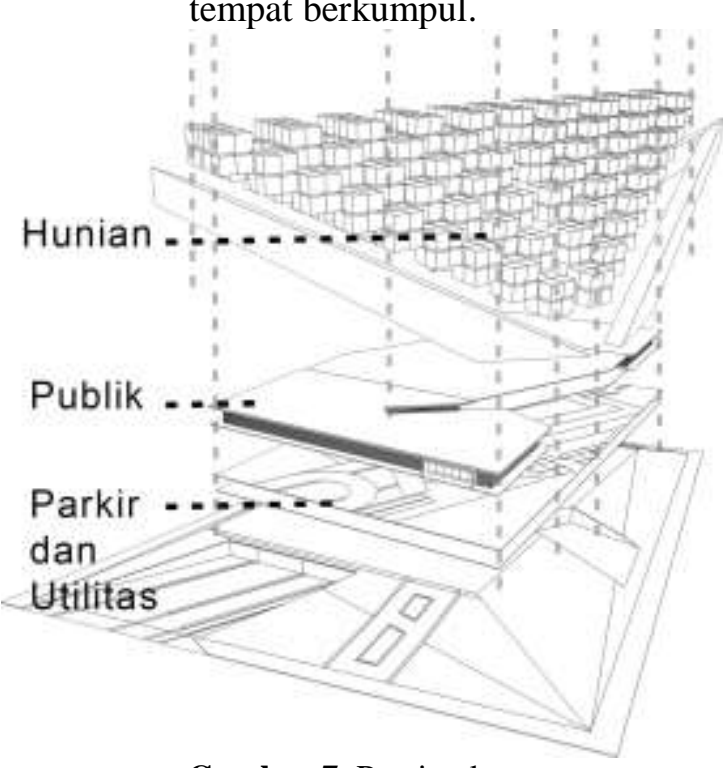

Gambar 7. Pemintakatan

\subsection{Analisis Tampilan dan Massa Bangunan}

1. Bentuk Dasar

Bentuk utama adalah bentuk prisma (lihat Gambar 8) yang merupakan gabungan dari bentuk persegi dan segitiga.

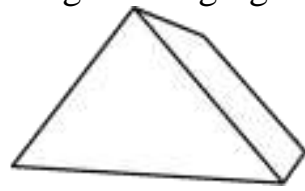

Gambar 8. Bentuk Dasar

\section{Perubahan Bentuk}

Bentuk dasar yang berupa prisma berkembang menjadi bentuk lainnya (lihat Gambar 9). Perubahan pertama dengan membesarkan bagian atas prisma dan mengecilkan bagian bawah prisma.

Perubahan selanjutnya dengan memutar posisi prisma pada tapak dan memotong bagian dalam bentuk prisma yang telah diubah. Perubahan bentuk kedua dibagi dengan kotak-kotak berukuran $7 \mathrm{~m} \mathrm{x}$ $7 \mathrm{~m}$.

Tahap terakhir (lihat Gambar 10) menggabungkan bentuk perubahan ketiga dengan bentuk taman.

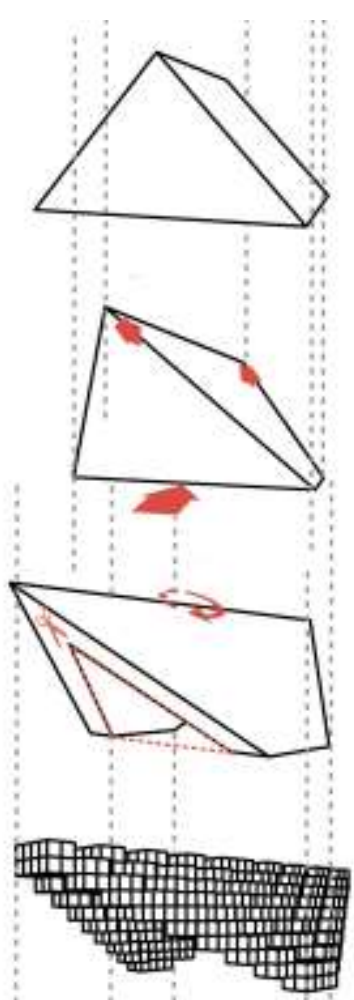

Gambar 9. Perubahan Bentuk

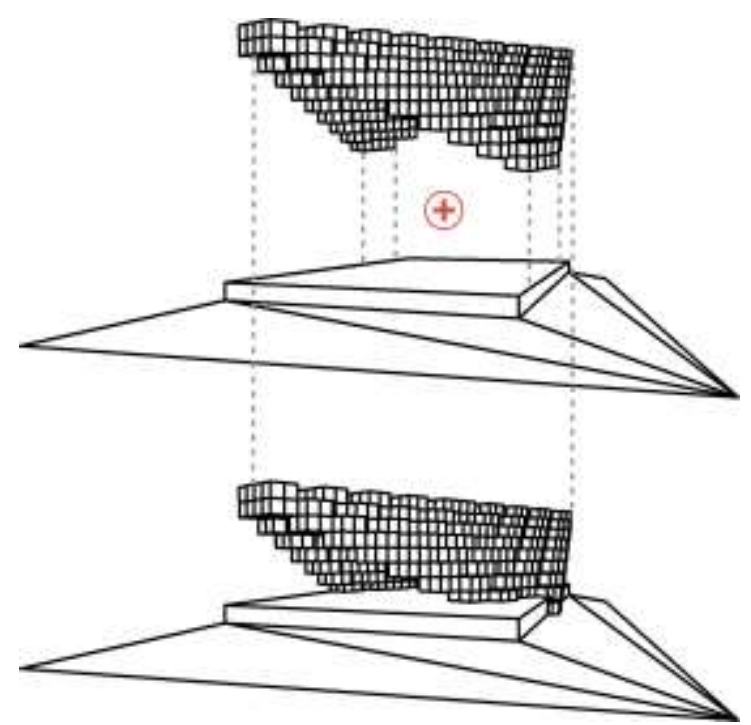

Gambar 10. Perubahan Bentuk

\subsection{Analisis Kegiatan, Pelaku dan Ruang}

1. Analisis Pelaku Kegiatan

Bertujuan untuk menentukan siapa saja yang akan menghuni dan menggunakan Hunian Vertikal dengan Penerapan Plug-In City.

Pelaku kegiatan terbagi menjadi dua yaitu :

a. Pelaku kegiatan utama 
Penghuni Rumah Adalah orang-orang yang tinggal di rumah (kapsul) sebagai tempat tinggalnya. Sasaran penghuni dari hunian vertikal ini merupakan keluarga yang baru menikah (suamiistri) atau yang sudah memiliki anak.

Penghuni rumah terdiri dari :

1) Suami.

2) Istri.

3) Anak

b. Pelaku kegiatan pendukung

1) Pengunjung

Adalah orang-orang yang mempunyai kepentingan dengan penghuni hunian vertikal maupun fasilitas pelayanan di hunian vertikal.

2) Pelayan

Merupakan orang-orang yang berkerja untuk melayani penghuni maupun yang bukan penghuni hunian vertikal serta orang yang bertanggung jawab terhadap semua penyelenggaraan kegiatan dan perawatan sarana dan prasarana hunian vertikal.

Pelaku kegiatan bagian pelayanan terdiri dari:
a) Pengelola hunian vertikal
b) Pengelola masjid
c) Petugas keamanan
d) Petugas kebersihan dan perawatan
e) Pemilik dan karyawan toko/restoran

\section{Analisis Kegiatan}

Kegiatan di Hunian Vertikal dengan Penerpan Plug-In City terbagi menjadi dua yaitu :

a. Kegiatan Utama

Berdasarkan hierarki kebutuhan Maslow seperti dikutip Budihardjo (1994), kebutuhan paling dasar manusia adalah hal yang berkaitan dengan fisik seperti makan, istrirahat, dan ekskresi (mandi). Kegiatan dasar tesebut akan berkembang sesuai dengan hierarki kebutuhan manusianya.

b. Kegiatan Pendukung
Merupakan kegiatang yang mendukung kegiatan utama, kegiatankegiatannya yaitu :

1) Rekreasi

2) Bersosial

3) Edukasi

4) Ibadah

5) Jual beli

6) Pelayanan kebersihan dan perawatan

7) Pelayanan keamanan

8) Operasional

3. Analisis Kebutuhan dan Ruang

Bertujuan untuk menentukan besaran ruang (lihat Tabel 1) dan tipe-tipe hunian pada Hunian Vertikal dengan Penerapan Plug-In City.

Perhitungan luas ruang dari kebutuan dasar manusia menghasilkan jumlah kurang lebih $24 \mathrm{~m}^{2}$ sudah termasuk sirkulasi $30 \%$. Dari jumlah minimal tersebut dapat ditentukan besaran modul untuk unit hunian. Modul yang digunakan adalah 3,5 m x 3,5 $\mathrm{m}$, ukuran tersebut dapat dilipat gandakan, namun untuk panjang atau menjorok ke luar $(3,5 \mathrm{~m})$ dibatasi dua kali yaitu $2(3,5 \mathrm{~m})=7$ $\mathrm{m}$. Maksimalnya dengan satu lantai adalah $3,5 \times 7=24,5 \mathrm{~m}^{2}$. Satu kaveling memiliki ukuran $3,5 \mathrm{~m} \mathrm{x} 7 \mathrm{~m}$.

Untuk ketinggian rumah tapak (landed house) terdapat aturan yang membatasi ketinggian dan jumlah lantai maksimal 3 lantai, pada hunian vertikal ini ketinggian tiap "lahan" atau kaveling dibatasi 2 lantai dengan tiap lantainya memiliki tinggi 3,5 m.

Satu kaveling hunian dapat dibuat menjadi dua lantai dan luas maksimal dari satu kaveling adalah 3,5 × 7 × 2 (lantai) $=49$ $\mathrm{m}^{2}$. Jika tiap modul (kotak hunian) berukuran $3,5 \mathrm{~m}$ x 3,5 m, maka jumlah maksimal tiap satu kaveling adalah 4 modul. Dua di lantai pertama dan dua di lantai kedua. Modul (kotak hunian) tidak terbatas pada ukuran 3,5 m x 3,5 m ukuran modul dapat bervariasi selama tidak melebihi batas ukuran. Untuk batas ukuran pada Hunian Vertikal dengan Penerapan Plug-In City, perkembangan maksimal ke samping dibatasi dua kaveling. Untuk hunian perkembangan paling maksimal adalah $2 \times 7$ $\mathrm{x} 7=98 \mathrm{~m}^{2}$. 
Untuk tipe-tipe hunian dibuat menjadi 3 tipe berdasarkan jumlah penghuni. Ratarata jumlah penghuni tiap rumah tangga di kota Semarang adalah 3,58 jiwa per rumah tangga. Diasumsikan bahwa tipe hunian kebanyakan adalah untuk hunian berpenghuni 3 dan 4 orang, sedangkan tipe hunian lainnya adalah hunian dengan 2 jiwa untuk jumlah penghuni kurang dari 3 .

Hunian dibuat dalam 3 macam berdasarkan jumlah penghuni yaitu :

a. Hunian dengan dua orang penghuni (suami dan istri).

b. Hunian dengan tiga orang penghuni (suami, istri dan anak).

c. Hunian dengan empat orang penghuni (suami, istri dan dua orang anak).

Tabel 1. Besaran Ruang

\begin{tabular}{|l|c|}
\hline Ruang & Luas Ruang \\
\hline Hunian & $9.408 \mathrm{~m}^{2}$ \\
\hline Publik & $5245 \mathrm{~m}^{2}$ \\
\hline Servis & $249 \mathrm{~m}^{2}$ \\
\hline Parkir & $10.900 \mathrm{~m}^{2}$ \\
\hline Jumlah & $26.194^{2}$ \\
\hline
\end{tabular}

\subsection{Analisis Struktur dan Utilitas}

1. Analisis Struktur

a. Struktur Plug-In City

Bentuk ini (lihat Gambar 11) memiliki struktur utama (core) tegak lurus ke atas yang berupa tabung dan dilengkapi crane di atasnya. Unit hunian ditata dengan melingkari struktur utama (core). Struktur untuk menahan beban unitnya menggunakan struktur kantilever.
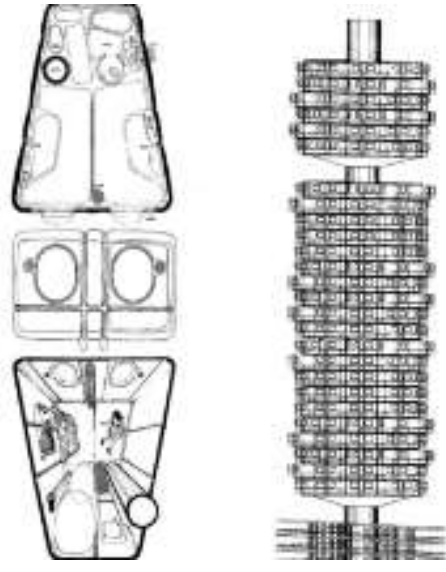

Gambar 11. Struktur Plug-In City (Sumber : Sadler, Simon, Archigram : Architecture Without Architecture, 2005)

\section{b. Struktur Nakagin Capsule Tower}

Nakagin capsule tower dikutip dari Slm (2011) memiliki dua struktur utama (core), masing-masing core menyangga beban dari kapsul yang sifatnya tidak permanen, dapat dipindahkan. Nakagin capsule tower memiliki 140 kapsul yang dipakai sebagai hotel. Berat dari masing-masing kapsul sekitar 4,1 ton.

Pada saat pembangunan, struktur utama dibangun lebih dulu, kemudian dengan crane tiap kapsul diangkut menuju struktur utama dan disambungkan. Sambungan kapsul ke struktur utama menggunakan empat titik penyangga, dua pada bagian bawah dan dua pada bagian atas (lihat Gambar 12).

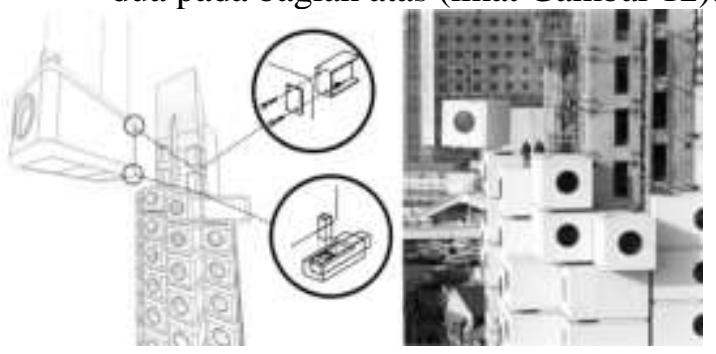

Gambar 12. Struktur Nakagin Capsule Tower (Sumber : Metalocus.es, Slowmedia.net, diolah oleh Luth, 2015)

Dari preseden struktur, ada tiga komponen utama dari struktur yang digunakan untuk plug-in city yaitu :

a. Struktur inti yang menjadi core atau inti dari bangunan hunian vertikal, dimana bentuk dan 
keadaannya tidak dapat diubah, dipindah maupun dibongkar pasang. Sedangkan ruang pada struktur inti berisi ruang untuk mendukung hunian (kapsul), seperti ruang untuk utilitas, sirkulasi vertikal (tangga dan lift) dan horizontal (penghubung ke tiap hunian.

b. Kapsul atau yang akan digunakan untuk hunian dalam plug-in city merupakan massa yang dapat diubah, dipindah maupun di bongkar pasang, kapsul ini disambungkan dengan struktur inti. Kapsul merupakan massa yang berupa modular supaya dapat dibongkar pasang dan mudah dipindah (tidak permanen). Untuk ukuran kapsul dibuat dengan lebar 3,5 $\mathrm{m}$ dan panjang $3,5 \mathrm{~m}$.

c. Crane merupakan penggerak dari hunian vertikal, memindahkan kapsul (hunian) ke tempatnya di struktur inti.

Komponen-komponen yang ada pada preseden plug-in city juga diterapkan pada Hunian Vertikal dengan Penerapan Plug-In City. Namun dengan perubahan-perubahan yang menyesuaikan, utamanya struktur inti yang digunakan.

\section{Analisis Utilitas}

Utilitas Hunian Vertikal dengan Penerapan Plug-In City, untuk sistem vertikalnya menggunakan shaft sebagai ruang bagi pipa air, kabel dan sampah. Shaft terbagi pada tiap lantai dengan sistem horizontal, dari shaft (air dan listrik) dihubungkan ke masing-masing hunian.

Tiap unit hunian sudah memiliki pipapipa utilitas yang berisi listrik, air bersih, air kotor dan air limbah. Pipa-pipa utilitas itu nantinya dihubungkan dengan pipa-pipa utilitas dari megastruktur yang tujuannya ke shaft.

\section{KESIMPULAN (KONSEP DESAIN)}

Hunian Vertikal dengan Penerapan Plug-In City merencanakan hunian yang dapat berkembang sesuai dengan perkembangan penghuninya, mengatasi permasalahan kebutuhan rumah dan keterbatasan lahan di Kota Semarang.

Pemecahan masalah tersebut adalah dengan membuat hunian vertikal yang tiap unit huniannya dapat bongkar pasang atau tidak permanen dan terhubung ke mega struktur sebagai struktur utama yang sifatnya permanen.

1. Konsep Hunian

Jumlah hunian pada Hunian Vertikal dengan Penerapan Plug-In City tidak tentu, hunian dapat berjumlah nol seperti Gambar 13 dan dapat berjumlah maksimal 98 unit (untuk hunian kaveling ganda) dan 196 unit (untuk hunian kaveling tunggal) seperti Gambar 15.

Hunian Vertikal dengan Penerapan Plug-In City di Semarang merencanakan untuk membuat hunian berjumlah (berdasarkan jumlah penghuni) seperti Gambar 14 :

1. Hunian dengan dua orang penghuni (suami dan istri) berjumlah 22 kaveling (berwarna hijau).

2. Hunian dengan tiga orang penghuni (suami, istri dan anak) berjumlah 9 kaveling (berwarna biru).

3. Hunian dengan empat orang penghuni (suami, istri dan dua orang anak) berjumlah 65 kaveling (berwarna merah).

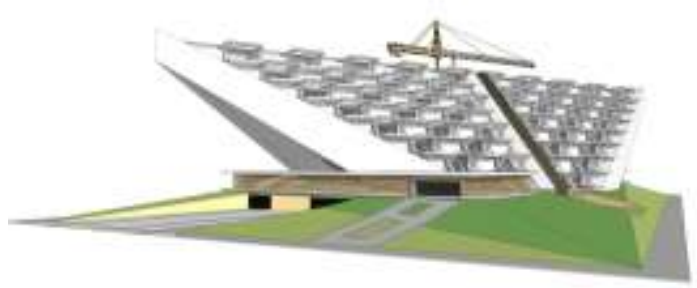

Gambar 13. Saat Kosong Hunian

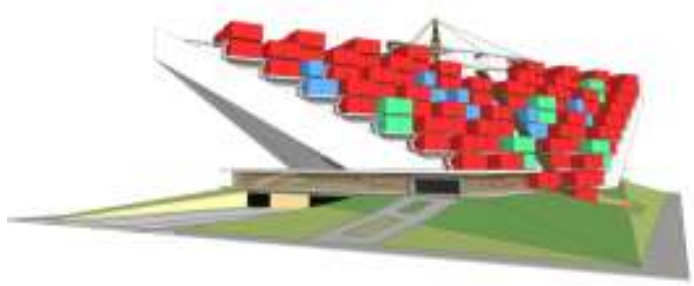

Gambar 14. Hunian yang Direncanakan 


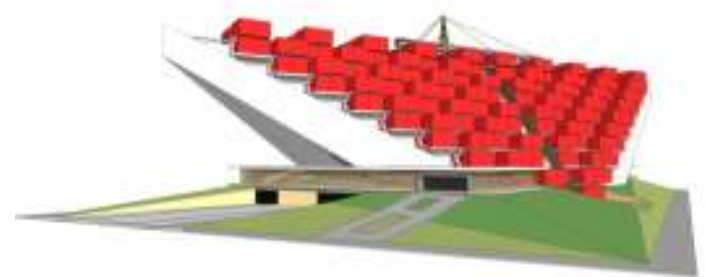

Gambar 15. Saat Penuh Hunian

2. Konsep Struktur

Struktur pada Hunian Vertikal dengan Penerapan Plug-In City (lihat Gambar 16, 17) terdiri dari tiga komponen :

1. Mega struktur merupakan struktur utama yang bersifat permanen yang menjadi tumpuan bagi unit hunian.

2. Unit hunian merupakan unit-unit yang bersifat tidak permanen, dapat dibongkar pasang, diubah dan dipindah.

3. Crane mempunyai peran utama sebagai pengangkut hunian dari dan menuju mega struktur.

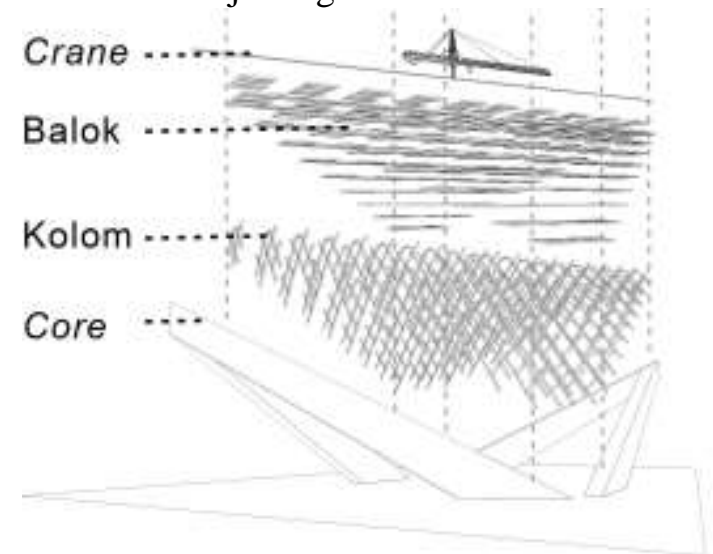

Gambar 16. Struktur

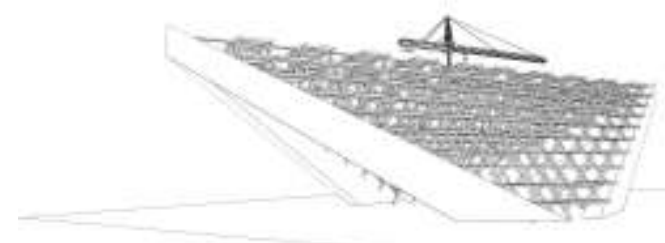

Gambar 17. Struktur

Proses pengangkutan hunian hingga penyambungan dengan megastruktur (lihat Gambar 18, 19, 20, 21, 22, 23, 24, $25)$.

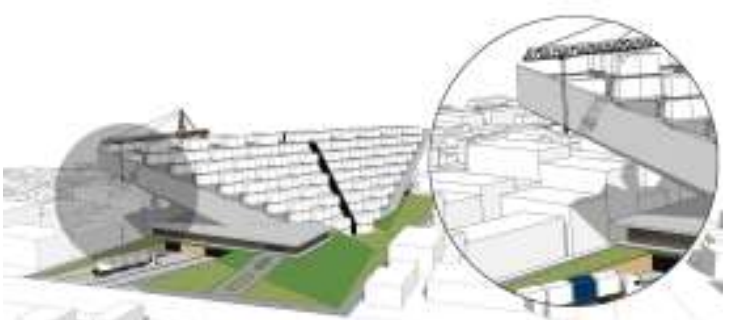

Gambar 18. Proses Pemasangan

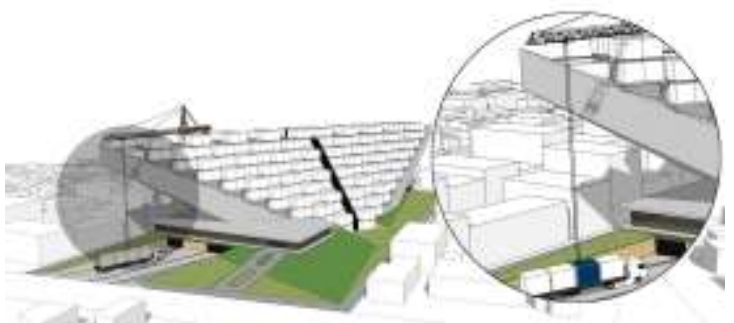

Gambar 19. Proses Pemasangan

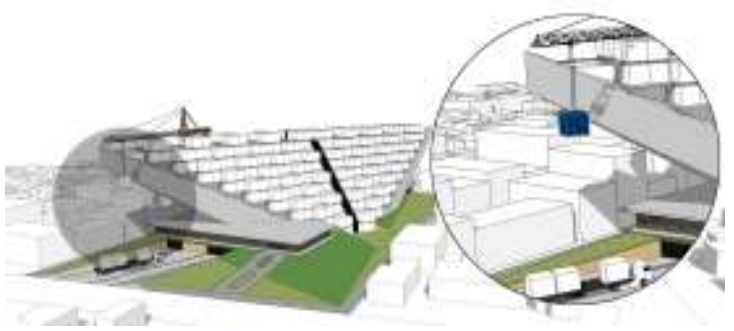

Gambar 20. Proses Pemasangan

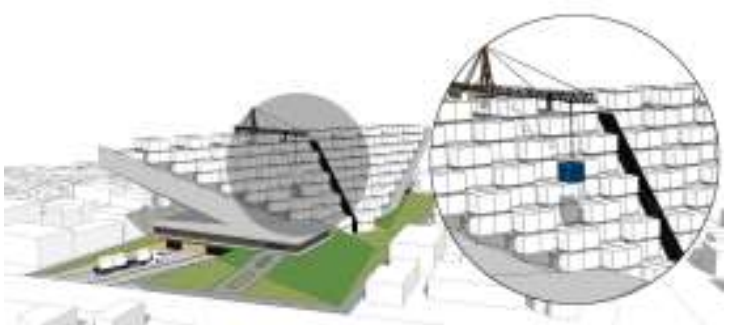

Gambar 21. Proses Pemasangan

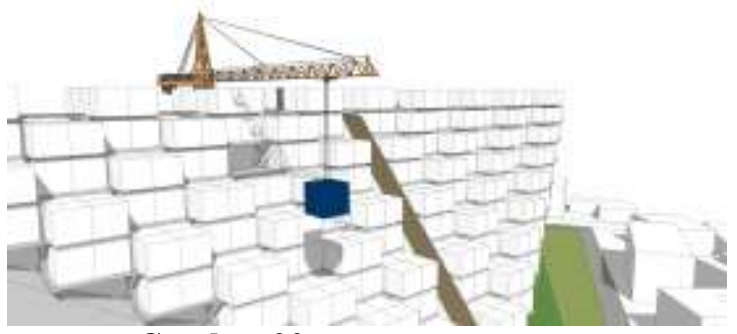

Gambar 22. Proses Pemasangan 


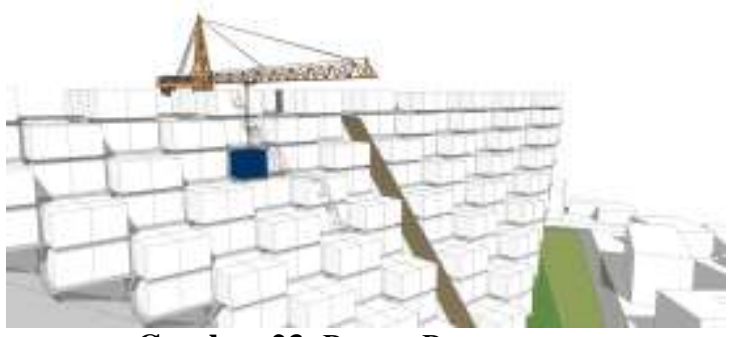

Gambar 23. Proses Pemasangan

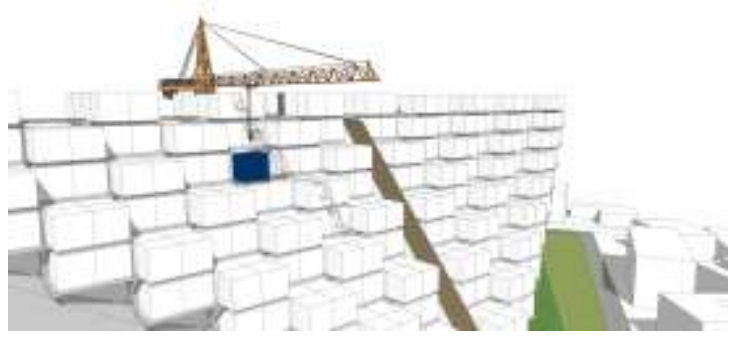

Gambar 24. Proses Pemasangan

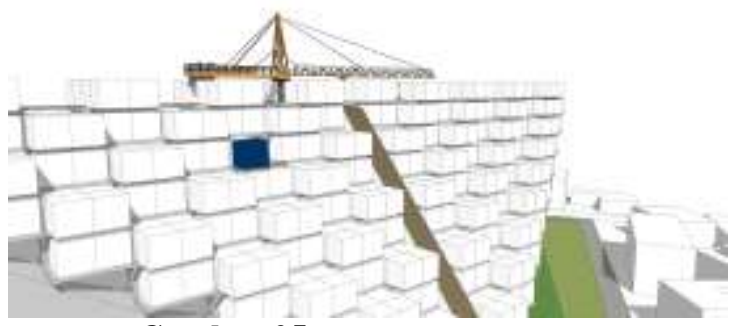

Gambar 25. Proses Pemasangan

Sambungan hunian dengan mega struktur (lihat Gambar 26).

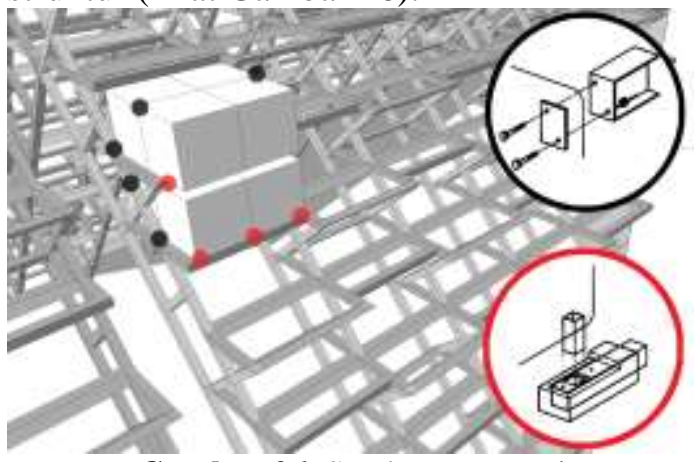

Gambar 26. Sambungan Hunian

(Sumber : Metalocus.es, diolah oleh Luth, 2015)

\section{REFERENSI}

Budihardjo, Eko 1994, Percikan Masalah Arsitektur, Perumahan, Perkotaan, edk 3, Gajah Mada University Press, Yogyakarta.

Sadler, Simon 2005, Archigram: Architecture without Architecture, MIT Press, Cambridge.

Slm, 2011, Nakagin Capsule Tower construction process, Slowmedia, http://slowmedia.net /news/2011/03/nct_ constructio.html, diakses 24 Februari 2015. 